\title{
Taxonomic studies on the 0-group eel larvae (Anguilla sp.) caught in the Sargasso Sea in 1979
}

\author{
Monika Schoth \\ Biologische Anstalt Helgoland (Zentrale); Notkestr. 31, \\ D-2000 Hamburg 52, Federal Republic of Germany
}

\begin{abstract}
More than 2000 0-group larvae (5.0-30.0 mm long) of both Atlantic Anguilla species were examined taxonomically. With regard to the total number of myomeres in A. rostrata and A. anguilla, an average difference between the two species of 6 to 8 myomeres was found in all size groups. 31 specimens (i.e. $1.76 \%$ ) exhibited 111 myomeres. The position of the last vertical blood vessel and the number of preanal myomeres turned out to be statistically different in both species; however, these differences cannot be used for species identification. The regression line for the position of the last vertical blood vessel according to the total number of myomeres indicates that individuals with a total of 111 myomeres may be $A$. anguilla. Measurements of total lengths revealed highly significant differences between the larvae of both eel species. It can be concluded that, on the average, $A$. rostrata $(\overline{\mathrm{x}}=15.70 \mathrm{~mm})$ hatched about two weeks before $A$ anguilla $(\overline{\mathrm{x}}=$ $12.32 \mathrm{~mm})$. On the other hand, results obtained from the biggest $A$. rostrata larvae $(29.5 \mathrm{~mm})$ and $A$. anguilla larvae $(23.5 \mathrm{~mm})$ make a spawning of $A$. rostrata likely two months before $A$. anguilla, when findings from hatching experiments with $A$. japonica are taken as a basis. There is no difference in the relative length of the intestine in either Anguilla species.
\end{abstract}

\section{INTRODUCTION}

Since Schmidt (1924) found both Atlantic species of Anguilla spawning in or near the Sargasso Sea no other significant studies have been published on this subject. During an expedition with two research vessels, F.R.V. "Anton Dohrn" and R.V. "Friedrich Heincke", of the Federal Republic of Germany, 3097 Anguilla larvae, 5.0 to $33.0 \mathrm{~mm}$ long, were caught during March/April 1979 in the Sargasso Sea between $19^{\circ}-31^{\circ} \mathrm{N}$ and $50^{\circ}-70^{\circ} \mathrm{W}$. The bigger larvae which belonged to an older age group of $A$. anguilla are treated in another paper (Kracht, 1982). Differences in enzyme patterns of the two species have been studied by Comparini \& Rodinó (1980). A comparison of species identification by myomere counting with that by electrophoretic characteristics has been made by Comparini \& Schoth (1982).

In order to prove the difference between $A$. rostrata and A. anguilla populations, thus confuting the theory of Tucker (1959), some other characteristics beside the total number of myomeres were examined: the position of the last vertical blood vessel and the number of the preanal myomeres (Jespersen, 1942). Apart from these meristic characteristics, morphometric characteristics were also studied. 


\section{MATERIAL AND METHODS}

Since the leptocephali of Anguilla species completely lack pigments in the body (Smith, 1979), they can easily be distinguished from other anguilliform leptocephali.

2164 Anguilla larvae smaller than $30.0 \mathrm{~mm}$ were separated on board the ship and preserved in $4 \%$ buffered formalin. Sample sorting in the laboratory gave an additional amount of $1043(=33.68 \%$ ) mostly smaller Anguilla leptocephali. Five specimens, longer than $30.0 \mathrm{~mm}\left(2 \times 31.0 \mathrm{~mm}_{i} 2 \times 31.5 \mathrm{~mm}_{i} 1 \times 32.0 \mathrm{~mm}\right)$, have not been considered in the analysis; later on they turned out to be $A$. rostrata. For information on the station net in the Sargasso Sea, the geographical distribution of the larvae and the methods of fishing, see Schoth \& Tesch (1982).

The Anguilla larvae were investigated for the meristic characteristics under a microscope with magnifying powers of 125 and 500. Measurements of morphometric characteristics were carried out under a dissecting microscope with the aid of an ocularmicrometer.

\section{RESULTS}

\section{Total number of myomeres}

To identify the species of Anguilla larvae one must count the total number of myomeres. This characteristic does not change during the eel's life cycle (Tesch, 1973).

The total number of myomeres could be counted in 1766 specimens. 871 were A. rostrata with $102-111$ myomeres (mean value: 106.96$) ; 895$ were distinguished as A. anguilla with 111-121 myomeres (mean value: 114.68). Specimens with 111 myomeres were treated as if $50 \%$ belonged to $A$. rostrata and $50 \%$ to A anguilla. (Fig. 1).

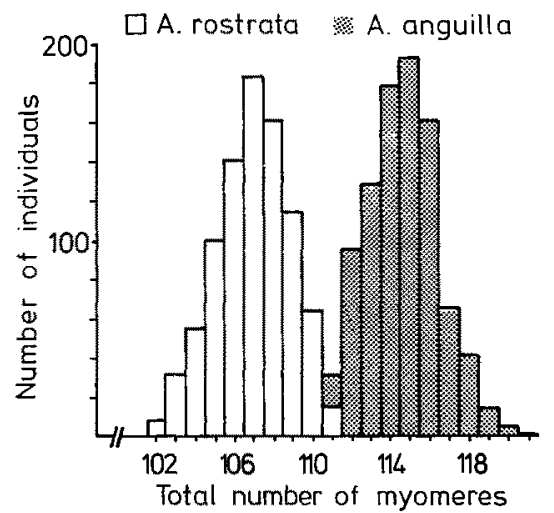

Fig. 1. Frequency distribution of the total number of myomeres for both Atlantic Anguilla species; A. rostrata: $\overline{\mathrm{x}}=106.96 ;$ s.e. $= \pm 0.06 ;$ s.d. $= \pm 1.91 ; \mathrm{n}=871 ; A$. anguilla: $\overline{\mathrm{x}}=114.68 ;$ s.e. $= \pm 0.06$; $\mathrm{s.d}= \pm 1.80 ; \mathrm{n}=895$

\section{Position of the last vertical blood vessel}

The position of the last vertical blood vessel, according to Smith (1979), is also a characteristic to be looked for when identifying leptocephali. It is especially helpful when distinguishing very small Serrivomer sp. from Anguilla sp. because of weak 
pigmentation in Serrivomer species. According to Jespersen (1942) "the situation of the blood vessels is determined according to the myomere which lies off the upper end of the vessel where it joins the aorta." In Anguilla spec. the last vertical blood vessel is situated between the 40-50th myomere (Smith, pers. communication), in Serrivomer spec. between the 30-37th myomere (Smith, 1979).

1402 Anguilla larvae of the 0-group were examined yielding 731 A. rostrata and 671 $A$. anguilla leptocephali. The difference between the mean myomere numbers up to the last vertical blood vessel (mean values: 46.00 for $A$. rostrata; 48.09 for $A$. anguilla) is

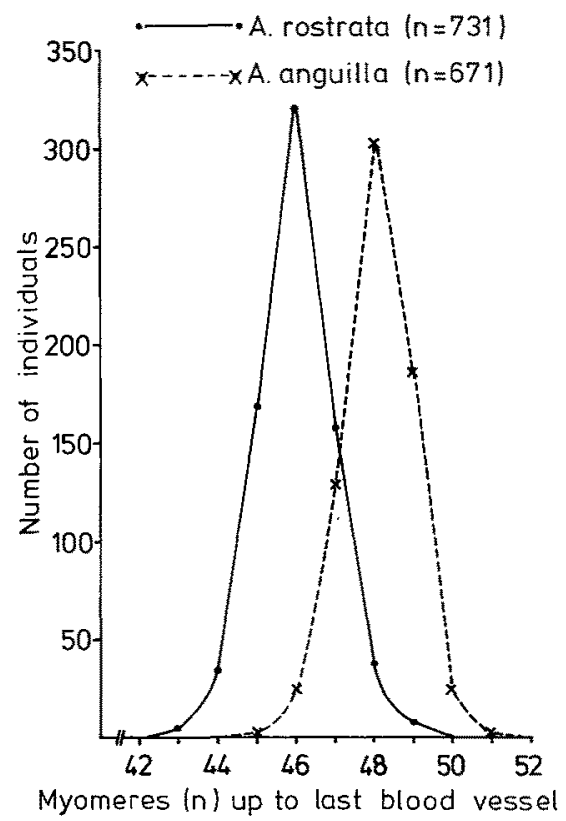

Fig. 2. Frequency distribution of the number of myomeres up to the last vertical blood vessel for $A$. rostrata: $\bar{x}=46.00 ;$ s.e. $= \pm 0.03 ;$ s.d. $= \pm 1.00 ; n=731$, and $A$. anguilla: $\overline{\mathrm{x}}=48.09$; s.e. $= \pm 0.03$; s.d. $= \pm 0.90 ; n=671$

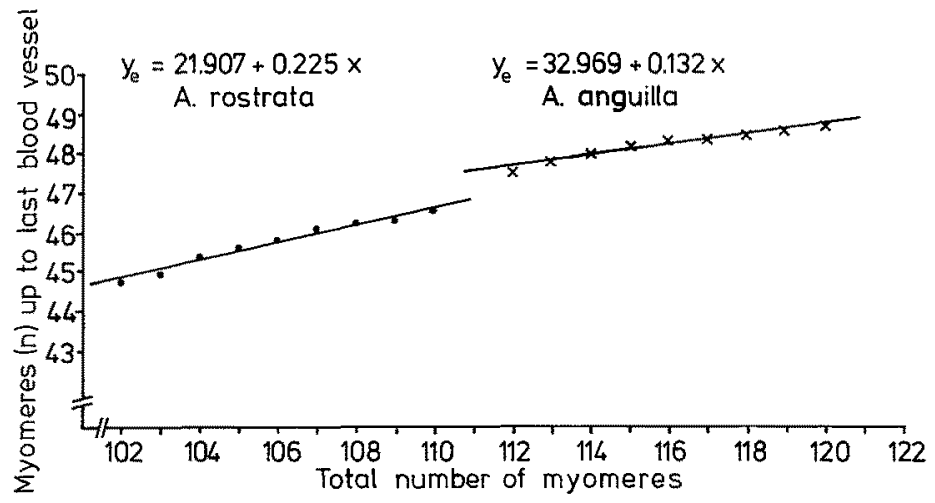

Fig. 3. Regression lines for the position of the last vertical blood vessel according to the total number of myomeres for $A$. rostrata and $A$, anguilla separately 
highly significant ( $\mathrm{t}-$ Test: $\mathrm{P}<0.001)$. Nevertheless, this characteristic alone cannot be used for the species identification of individuals (see Fig. 2).

Figure 3 shows that the myomeres up to the last vertical blood vessel are positively correlated with the total number of myomeres and that the regression lines are different for both species.

\section{Preanal myomeres}

Concerning the number of preanal myomeres, Ford (1931) examined those of A. anguilla leptocephali and glass eels under the aspect of a change during metamorphosis. He found that the anus of a glass eel lies beyond the 35 th, that of the leptocephalus beyond the 71 st myomere.

The position of the anus in $152 \mathrm{~A}$, rostrata and $311 \mathrm{~A}$. anguilla larvae has been examined as described by Jespersen (1942). Figure 4 shows the frequency distribution of preanal myomeres for both species (mean values: 64.68 for $A$. rostrata; 66.56 for $A$. anguilla). The difference is highly significant (median test: $\mathrm{P}<0.001$ ). Figure 5 demonstrates that the number of preanal myomeres increases with the number of the total myomeres.

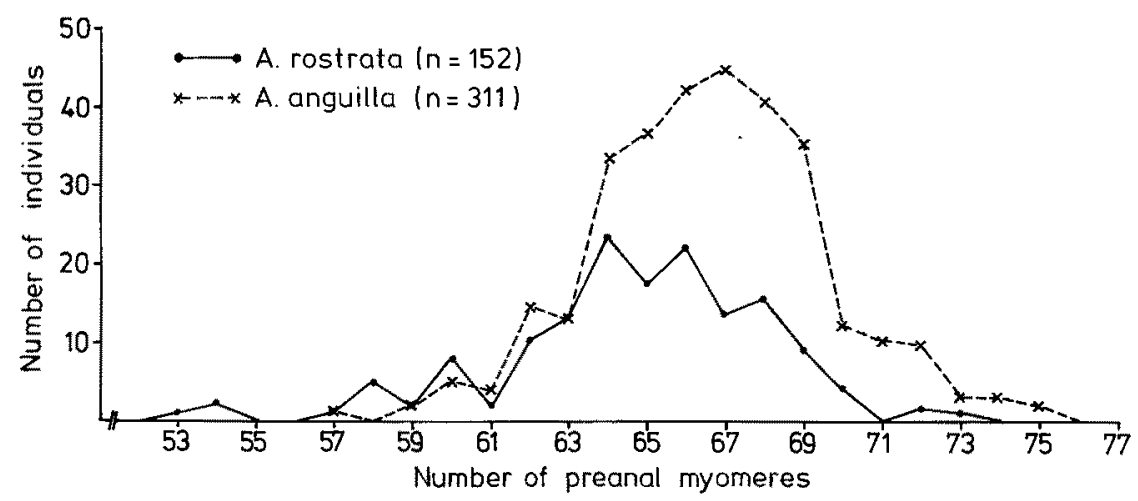

Fig. 4. Frequency distribution of the preanal myomeres for $A$. rostrata: $\bar{x}=64.68$; s.e. $= \pm 0.27$; s.d. $= \pm 3.41 ; \mathrm{n}=152$, and for $A$. anguilla: $\overline{\mathrm{x}}=66.56 ;$ s.e. $= \pm 0.16 ;$ s.d. $= \pm 2.94 ; \mathrm{n}=311$

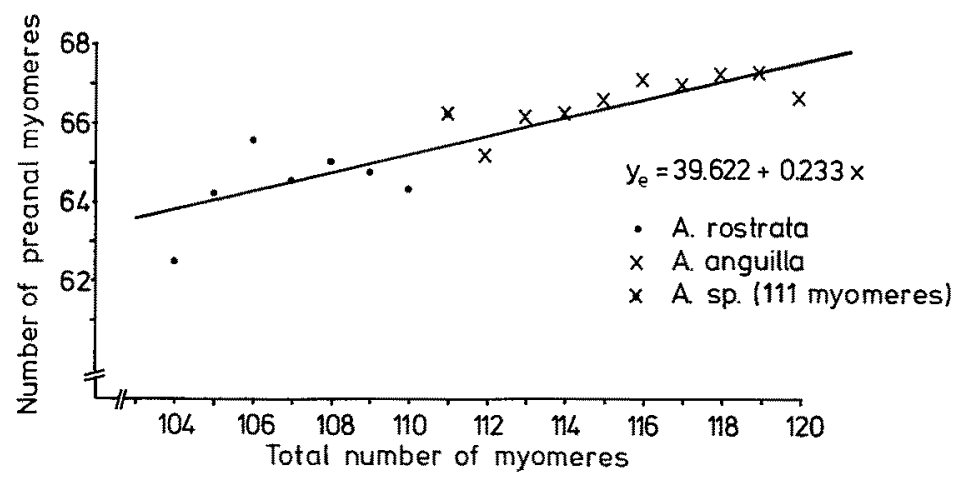

Fig. 5. Common regression line for the preanal myomeres of the Atlantic Anguilla larvae (0-group) 


\section{Total lengths of the Anguilla larvae}

The total lengths of 1735 Anguilla leptocephali were measured to $0.5 \mathrm{~mm}$. Figure 6 shows the frequency distribution of the total lengths in both species. The difference between the two mean values (15.70 mm for $A$. rostrata; $12.32 \mathrm{~mm}$ for $A$. anguilla) is highly significant $(\mathrm{P}<0.001$ [t-test]); i.e. $A$. rostrata and $A$. anguilla really represent two different populations. Attempts to find out whether specimens with 111 myomeres belong to $A$. rostrata or $A$. anguilla were not successful, since the low number of 31 individuals comprising 13 classes does not give an exact frequency distribution.

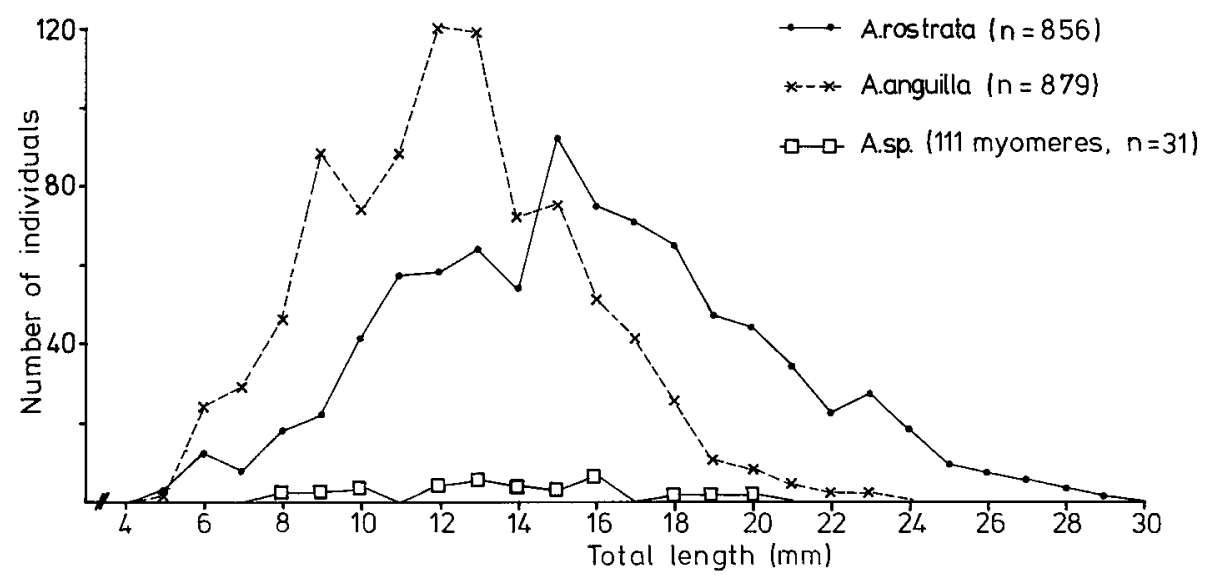

Fig. 6. Frequency distribution of the Anguilla leptocephali (0-group) in the length classes (mm); $A$. rostrata: $\overline{\mathrm{x}}=15.70 \mathrm{~mm}$; s.e. $= \pm 0.12 \mathrm{~mm}$; s.d. $= \pm 3.48 \mathrm{~mm} ; \mathrm{n}=856 ;$ A. anguilla: $\overline{\mathrm{x}}=12.32 \mathrm{~mm}$; s.e. $= \pm 0.11 \mathrm{~mm}_{;}$s.d. $= \pm 3.21 \mathrm{~mm}_{i} \mathrm{n}=879 ; A$. spec. $(111 \mathrm{myom}):. \overline{\mathrm{x}}=13.45 \mathrm{~mm}$; s.e. $= \pm 0.55$ $\mathrm{mm}$; s.d. $= \pm 3.08 \mathrm{~mm} ; \mathrm{n}=31$

\section{Relative length of the intestine}

834 A. rostrata and $906 A$, anguilla larvae were measured to determine the ratio of the intestinal length to the total body length (Fig. 7). The mean values $(79.65 \%$ for A. rostrata; $79.11 \%$ for $A$. anguilla) are not significantly different, so that the relative intestinal length cannot be used as a species characteristic. A slightly decreasing length of the intestine was found with increasing body length in both species. The ratios were $1.31: 1$ at $5 \mathrm{~mm}$ body length and 1.33:1 at $29 \mathrm{~mm}$ body length.

\section{DISCUSSION}

The Atlantic eel species, $A$. rostrata (Le Sueur) and $A$. anguilla (L.), can be distinguished by the total number of myomeres or vertebrae. Unfortunately, it is not certain that the number of myomeres tallies with the number of vertebrae. According to Jespersen (1942) there is, on the average, one more myomere than vertebrae in adult eels. In $A$. rostrata he found 103-111 ( $\overline{\mathrm{x}}=107.25)$ vertebrae and $104-111(\overline{\mathrm{x}}=108.17)$ 


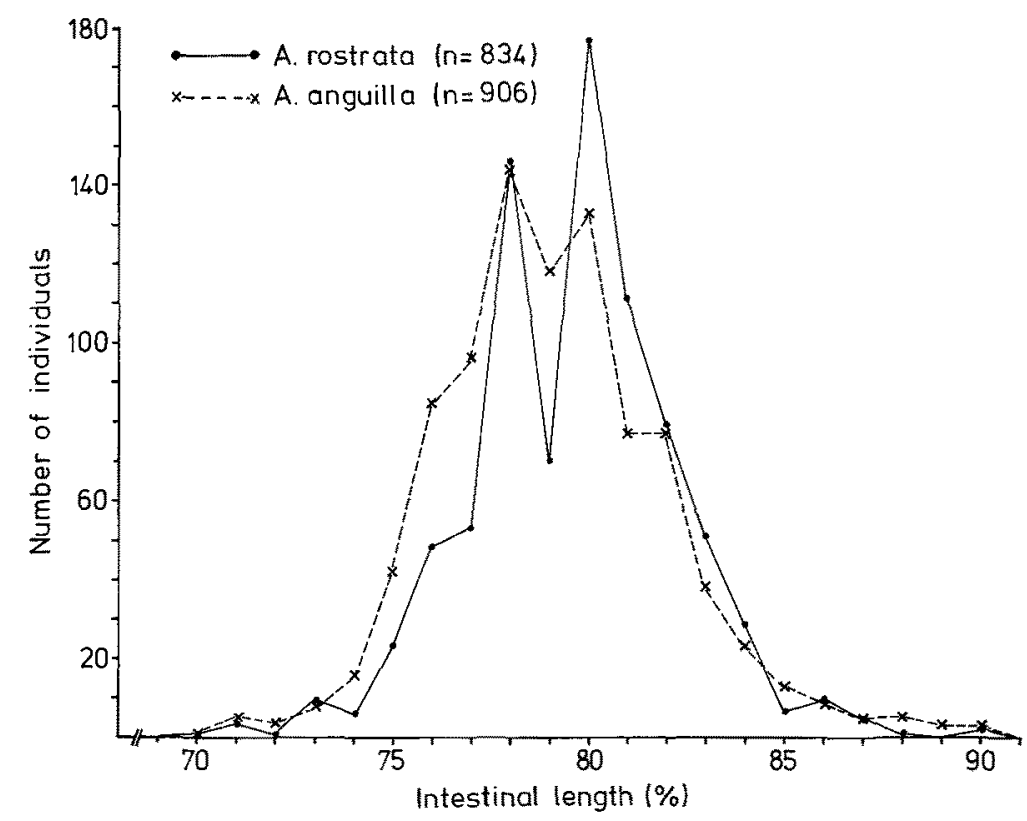

Fig. 7. Frequency distribution of the relative length of the intestine in $\%$ of the total length for $A$. rostrata: $\overline{\mathrm{x}}=79.65 ;$ s.e. $= \pm 0.09 ;$ s.d. $= \pm 2.68 ; \mathrm{n}=834$, and for $A$. anguilla: $\overline{\mathrm{x}}=79.11$; s.e. $= \pm 0.09 ;$ s.d. $= \pm 2.96 ; \mathrm{n}=906$

myomeres; in $A$. anguilla $110-119(\overline{\mathrm{x}}=114.73)$ vertebrae and $112-119(\overline{\mathrm{x}}=115.58)$ myomeres. Ege's results (1939) for $A$. rostrata were $103-111(\overline{\mathrm{x}}=107.23)$ vertebrae and $110-119(\overline{\mathrm{x}}=114.73)$ vertebrae for $A$. anguilla. Vladykov \& March (1975) found 101-111 $(\overline{\mathrm{x}}=105.13)$ myomeres in A. rostrata and 109-116 $(\overline{\mathrm{x}}=111.76)$ myomeres in $A$. anguilla. Kleckner \& McCleave's investigations (1980) resulted in $102-110(\overline{\mathrm{x}}=106.83)$ myomeres for $A$. rostrata and $112-119(\overline{\mathrm{x}}=114.48)$ myomeres for $A$. anguilla.

Boëtius (1980) presented data of the total number of vertebrae taken from samples of European and American eels and found 103-112 $(\bar{x}=107.19)$ vertebrae in the latter and $104-120(\bar{x}=114.62)$ in the former. In the samples of European eel, 17 specimens out of 15,854 had less than 109 vertebrae.

The present material revealed that $A$. rostrata has $102-111(\overline{\mathrm{x}}=106.96)$ myomeres and $A$. anguilla 111-121 $(\overline{\mathrm{x}}=114.68)$. These mean values are nearly the same as reported by Kleckner \& McCleave (1980) and Boëtius (1980); however, they are higher than the values presented by Vladykov \& March (1975) and lower than those given by Jespersen (1942). Vladykov \& March (1975) suggested that their values were too low because of methodological reasons. Actually, it is difficult to count myomeres in very small leptocephali; especially the last two in the tip of the tail seem to be left to the subjectivity of the investigator (Boëtius, Smith, Kleckner, McCleave, personal communications).

However, all investigators found an interspecific mean difference of 6-8 myomeres or vertebrae; a difference found in even very small specimens that are just a few days old. This refutes Tucker's theory (1959) that there is a higher number of myomeres in $A$. 
anguilla caused by drifting in waters of low temperatures on the way to Europe. On the other hand, 6-8 myomeres more or less would be equivalent to a changing rate of more than $7 \%$. This seems too high to have been induced by higher or lower temperatures.

Another point of Tucker's theory (1959) was that different temperatures during embryonal development could induce the higher number of vertebrae in some of the descendants of $A$. rostrata. This would imply that eggs of the same species are spawned in different water layers or sink to different depths with highly different temperatures. As, in the present material, very small specimens of both species came from the same hauls (Schoth \& Tesch, 1982) this seems improbable. According to Blaxter (1969) there usually is a V-relation in changes of vertebrae with different temperatures, i.e. the mean number of vertebrae is lowest when the eggs develop at medium water temperatures, whereas relatively higher and lower water temperatures lead to higher vertebrae numbers. Fonds et al. (1974) investigated the influence of temperature and salinity on embryogenesis and vertebrae number of Belone belone and observed an average difference in the number of vertebrae of about 2.2 (which ist $2.7 \%$ ). An average difference of $2.7 \%$ for the Anguilla species would lead to a mean difference of 3 myomeres based on specimens with 111 myomeres.

Electrophoretic investigations on board the R.V. "Anton Dohrn" during the cruise gave different enzyme patterns in both species. For $76.9 \%$ of the investigated specimens, the myomeres of which had been counted before electrophoresis was performed, species identification by myomere counting was in accordance with the results obtained by electrophoretic analysis (Comparini \& Schoth, 1982).

A point of uncertainty is the exact distinction between the two species under consideration as myomere counts overlap. Jespersen (1942) considered specimens with 111 myomeres to be $A$. rostrata; Kleckner \& McCleave (1980) omitted specimens with 111 myomeres from their calculations. Boëtius (1980) found a maximum of overlapping at 111 vertebrae; Schmidt (1924) divided individuals with 111 myomeres between the two species proportionally. I have proceeded in a similar fashion with the present material, although Boëtius \& Boëtius (1967) found twice as many glass eels with 111 vertebrae in $A$. anguilla populations as there are in those of $A$. rostrata.

Concerning the position of the last vertical blood vessel and the number of preanal myomeres, there are highly significant differences between the two species, but these characteristics cannot be used for individual species identification.

Schmidt (1924) concluded from measurements of $A$. rostrata and $A$. anguilla larvae taken over several months that the American eel spawns about two months earlier than the European eel. The mean body lengths of the present material revealed a highly significant difference between the two species. Length classes over $23.5 \mathrm{~mm}$ were not represented by $A$. anguilla at all but by $A$. rostrata. Thus Schmidt's conclusion (1924) that $A$. rostrata spawns earlier than $A$. anguilla seems to be confirmed. Yamamoto \& Yamauchi (1974) were successful in hatching eggs of $A$. japonica. They observed the growth of the larvae from $2.9 \mathrm{~mm}$ at the hatching point to $6.2 \mathrm{~mm}$ on the 5th day in water of $23^{\circ} \mathrm{C}$ temperature. Yamauchi et al. (1976) reared larvae in water of $19^{\circ} \mathrm{C}$ temperature. The larvae measured $6.2 \mathrm{~mm}$ on the 7 th day and $7.0 \mathrm{~mm}$ on the 14 th day of larval life. Provided these results from laboratory experiments with $A$. japonica are transferable to the closely related Atlantic Anguilla species then $A$. rostrata larvae hatched, on an average, about two weeks before $A$. anguilla eggs, on an average, ripened. Hence, the 
larger $A$, rostrata larvae $(29.5 \mathrm{~mm})$ could have hatched up to two months before $A$. anguilla $(23.5 \mathrm{~mm})$.

As reported by Tesch (1973), the Atlantic freshwater eels have the greatest relative length of the intestine while they are leptocephali. Berndt (1938) found a gut length of $63 \%$ related to the total length in a $75 \mathrm{~mm}$ A. anguilla leptocephalus. For glass eels he noticed a decrease of up to $38 \%$. Schmidt (1916) examined the ratio between body length and length of the tail (anocaudal length) in larvae of the European eel; in leptocephali ranging between 15-85 mm body length, the ratio decreases with increasing body size. These observations are in agreement with the findings obtained from the present material.

Acknowledgements. These results are part of a thesis (Diplomarbeit im Fachbereich Biologie der Universität Hamburg, Institut für Hydrobiologie und Fischereiwissenschaft). I wish to thank Dr. F.W. Tesch for the chance to participate on the cruise, Prof. Dr. E. Braum and Prof. Dr. D. Schnack for their critical discussion of my results, Drs. I. and J. Boëtius and D. G. Smith for supplying much of the information on leptocephali identification, Mr. Marschall, Mrs. C. Schuster and Mrs. Berger for their assistance in the preparation of the manuscript.

\section{LITERATURE CITED}

Berndt, O., 1938. Morphologie und Histologie des Rumpfdarmes von Anguilla fluviatilis und die Veränderungen desselben ìm Individualzyklus. - Zool. Jb. (Anat. Ontogenie Tiere) 64, 437-482.

Blaxter, J. H. S., 1969. Development: Eggs and larvae. In: Fish physiology. Ed. by W. S. Hoar \& D. J. Randall. Acad. Press, New York, 3, 177-252.

Boëtius, I. \& Boëtius, J., 1967. Eels, Anguilla rostrata, Le Sueur, in Bermuda. - Vidensk. Meddr dansk naturh. Foren. 130, 63-84.

Boëtius, I. \& Boëtius, J., 1967. Studies in the European eel, Anguilla anguilla (L.). - Meddr Danm. Fisk. - og Havunders. 4 (11), 339-405.

Boëtius, J., 1980. Atlantic Anguilla: A presentation of old and new data of total numbers of vertebrae with special reference to the occurrence of Anguilla rostrata in Europe. - Dana 1, 93-112.

Comparini, A. \& Rodinó, E., 1980. Electrophoretic evidence for two species of Anguilla leptocephali in the Sargasso Sea. - Nature, Lond. 287, 435-437.

Comparini, A. \& Schoth, M., 1982. Comparison of electrophoretic and meristic characters of 0-group eel larvae from the Sargasso Sea. - Helgoländer Meeresunters. 35, 289-299.

Ege, V., 1939. A revision of the genus Anguilla (Shaw). - Dana-Rep. 3 (16), 1-256.

Fonds, M. Rosenthal, H. \& Alderdice, D. $F_{.,}$1974. Influence of temperature and salinity on embryonic development, larval growth and number of vertebrae of the garfish, Belone belone. In: Early life history of fish. Ed. by J. H. S. Blaxter. Springer, Heidelberg, 509-525.

Ford, E., 1931. Changes in length during the larval life and metamorphosis of the freshwater eel (A. vulgaris, Turt). - J. mar. biol. Ass. UK 17, 987-1000.

Jespersen, P., 1942. Inda-Pacific leptocephalids of the Genus Anguilla. - Dana-Rep. 4 (22), 1-128.

Kleckner, R. \& McCleave, J. D., 1980. Spatial and temporal distribution of $A$. rostrata and $A$. anguilla leptocephali found in North-American ichthyoplankton collections. - C.M./ICES, M21.

Kracht, R., 1982. On the geographic distribution and migration of I- and II-group eel larvae as studied during the 1979 Sargasso Sea Expedition. - Helgoländer Meeresunters. 35, 321-327.

Schmidt, J., 1916. On the early larval stages of the freshwater-eels (Anguilla) and some other NorthAtlantic muraenoids. -- Medd. Komm. Havunders. (Fiskeri) 5 (4), 1-20.

Schmidt, J., 1924. The breeding places of the eel. - A. Rep. Smithson. Instn. 1924, 279-316.

Schoth, M. \& Tesch, F.-W., 1982. Spatial distribution of the 0-group eel larvae (Anguilla sp.) in the Sargasso Sea. - Helgoländer Meeresunters. 35, 309-320.

Smith, D. G., 1979. Guide to the leptocephali (Elopiformes, Anguilliformes and Notacanthiformes). - NOAA tech. Rep. NMFS Circ. 424, 1-36. 
Tesch, F.-W., 1973. Der Aal. Parey, Hamburg, 306 pp.

Tesch, F.-W., Kracht, R., Schoth, M., Smith, D. G. \& Wegner, G., 1979. Report on the eel expedition of FRV "Anton Dohrn" and RK "Friedrich Heincke" to the Sargasso Sea 1979. - C.M./ICES, M6.

Tesch, F.-W., 1980. Report on the available data of the Atlantic Anguilla larvae, presented to the ICES Planning Group for the Atlantic Eel Expedition. - C.M./ICES, $M 7$.

Tucker, D. W., 1959. A new solution to the Atlantic eel problem. - Nature, Lond. 183, 495-501.

Vladykov, V. D. \& March, H., 1975. Distribution of leptocephali of the two species of Anguilla in the western North Atlantic based on collections made between 1933 and 1968. - Syllogeus 6, 1-33.

Yamamoto, K. \& Yamauchi, K., 1974. Sexual maturation of Japanese eel and production of eel larvae in the aquarium. - Nature, Lond. 251, 220-222.

Yamauchi, K., Nakamura, M., Takahashi, H. \& Takano, K., 1976. Cultivation of larvae of Japanese eel. - Nature, Lond. 263, 412. 